\title{
PERFORMANCE EVALUATION OF A LOCALLY DEVELOPED CASSAVA CHIPPING MACHINE
}

\author{
B. O. Bolaji ${ }^{1}$, S. B. Adejuyigbe ${ }^{2}$ and S. P. Ayodeji ${ }^{2}$ \\ ${ }^{1}$ Department of Mechanical Engineering \\ University of Agriculture, Nigeria \\ bobbolaji2007@yahoo.com \\ ${ }^{2}$ Department of Mechanical Engineering \\ Federal University of Technology, Nigeria \\ samueladejuyigbe@yahoo.com
}

\begin{abstract}
A cassava chipping machine was designed and constructed, and its performance evaluated. The results showed that motor speed has significant effects on chipping capacity, chipping efficiency, and chips geometry. The higher the motor speed, the higher the chipping capacity and the lower the chipping efficiency of the machine. The machine has a maximum capacity of $245 \mathrm{kgh}^{-1}$ at $500 \mathrm{rpm}$, and maximum chipping efficiency of $92.6 \%$ at a speed of $300 \mathrm{rpm}$. The overall best performance of the machine is obtained at a speed of $400 \mathrm{rpm}$ with chipping efficiency of $86.5 \%$ and chipping capacity of $240 \mathrm{kgh}^{-1}$.

\section{OPSOMMING}

Die vertoning van ' $\mathrm{n}$ prototype spaandermasjien is bepaal na ontwerp en vervaardiging. Die resultate toon dat motorsnelheid ' $n$ betekenisvolle invloed het op spaanderuitset, spaanderrendement en spaandervorm. Hoër snelheid verhoog die spaanderuitset, maar tegelyke tyd verlaag die prosesrendement. Die maksimum prosesuitset is 245 kilogram per uur teen 500 omwentelinge per minuut. In den breede is die beste vertoning by 40 omwentelinge per minuut by ' $n$ rendement van $86.5 \%$ en ' $n$ uitset van 240 kilogram per uur.
\end{abstract}




\section{INTRODUCTION}

Root and tuber crops are abundant in the rural areas of most developing countries, and are often regarded as a cheap food. Increased production of root crops in Nigeria has brought about the need for the development of appropriate processing technology. Cassava (Manihot esculenta crantz) was introduced into Africa in the latter half of the $16^{\text {th }}$ century from Central America, where its tubers have been used through the ages as a basic food [1].

The importance of cassava as a staple food in Africa has continued to grow because it possesses properties such as tolerance to drought, poor soils, and even neglect. It is grown in over 30 African countries. Nearly 200 million people rely on cassava as a staple food, each person consuming an average of over $100 \mathrm{~kg}$ of the crop a year. In certain marginal areas and in regions fraught by civil wars and other crises, cassava is often the only readily available food crop [1].

Presently, cassava is one of the most important and widely grown food crops in Nigeria. Over two-thirds of the total production of cassava goes to the fresh food market for human consumption; the rest is used for animal feed, production of ethanol for fuel, and raw material for starch production industries [2].

The perishable nature of cassava tubers poses a serious storage problem. Once detached from the growing plant, cassava tubers will not normally keep for more than three to four days without being processed in some way; otherwise deterioration sets in. The deterioration is caused by microbial infections and physiological factors like loss of moisture [3]. There is therefore an ever-increasing need to process tubers into some stable form quickly - as soon as they are harvested. Processing is also necessary to eliminate or reduce the poisonous cyanide contained in raw cassava, and to give the finished product a good taste [4].

A vital step in processing cassava is the reduction of the peeled fresh roots into smaller sizes by slicing or chipping. In the traditional method of cassava chipping, knives and machetes are used mechanically to reduce peeled cassava to small sizes. According to Ariavie and Ohwovoriole [5], the manual method is very tedious, slow, and dangerous, as body injuries are easily sustained. Also, high labour inputs and high processing losses are incurred in large scale processing.

Jekayinfa et al. [3], Adejuyigbe and Bolaji [6] have reported that, for the mechanization of agriculture in Nigeria to succeed, it must be based on indigenous design, development, and manufacture of most of the required machines and equipment, to ensure their suitability for the crops as well as for the farmers' technical and financial capabilities. Some notable contributions to the mechanization of the cassava processes include Ohwovoriole et al. [7], Igbeka et al. [4], Ariavie and Ohwovoriole [5], Ukatu [8], and Jekayinfa et al. [3].

These contributions are in the area of cassava tuber peeling and grating. It is necessary to mechanize the chipping process in order to overcome the difficulties of handling large-scale processing with the traditional method, since the manual chipping operation alone creates a bottleneck. This paper reports on the design and construction of a cassava chipping machine using locally-sourced materials, with the 
aim of increasing the rate of processing cassava tubers into a stable form as soon as they are harvested. The performance of the machine was also evaluated.

\section{MATERIALS AND METHODS}

\subsection{Design theory}

The force required to chip cassava is equal to the reaction offered by the cassava tuber $\left(R_{t}\right)$, which is equal to the sum of shearing force $\left(F_{s}\right)$ and frictional force $\left(F_{R}\right)$ between the chipping plate and the tuber. Therefore:

$R_{t}=F_{s}+F_{R}$

Since $F_{R}=\mu F_{s}$, Eq. (1) can be written as:

$R_{t}=F_{s}+\mu F_{s}$

therefore, $\mathrm{R}_{\mathrm{t}}=\mathrm{F}_{\mathrm{s}}(1+\mu)$

and torque on the shaft $M_{t}=R_{t} \times r$

where $\quad \mu=$ coefficient of friction

$r=$ radius of the chipping plate

The shaft diameter ' $d$ ', is obtained from the ASME code equation for commercial steel shafting [9]:

$d^{3}=\frac{16}{\pi S_{s}} \sqrt{\left(K_{b} M_{b}\right)^{2}+\left(K_{t} M_{t}\right)^{2}}$

where $\mathrm{S}_{\mathrm{s}}=$ allowable stress for shaft with key way $\left(\mathrm{Nm}^{-2}\right)$

$M_{b}=$ bending moment $(\mathrm{Nm})$

$\mathrm{K}_{\mathrm{b}}=$ combined shock and fatigue factor applied to bending moment

$\mathrm{K}_{\mathrm{t}}=$ combined shock and fatigue factor applied to torsional moment

The power transmitted $(\mathrm{P})$ through the belt drive is given as:

$P=\left(T_{1}-T_{2}\right) V$

where $\quad T_{1}=$ belt tension in the tight side $(\mathrm{N})$

$\mathrm{T}_{2}=$ belt tension in the loose side $(\mathrm{N})$

$\mathrm{v}=$ belt speed $\left(\mathrm{ms}^{-1}\right)$

The maximum tension in the tight side of the belt depends on the allowable stress of the belt material, and the tension in the slack side is obtained from [9]:

$\frac{T_{1}-m v^{2}}{T_{2}-m v^{2}}=e^{f \alpha / \sin 1 / 2 \theta}$

where $\quad m=$ mass of belt per unit length $\left(\mathrm{kgm}^{-1}\right)$

$f=$ coefficient of friction between belt and pulley 


$$
\begin{aligned}
& \alpha=\text { angle of wrap (radian) } \\
& \theta=\mathrm{V} \text {-belt angle (degree) }
\end{aligned}
$$

\subsection{Machine description and construction details}

The cassava chipping machine is shown in Figure 1 . The machine is powered by electricity. It has four major components: the hopper/feeding chute, the chipping units, the power unit, and the machine frame.

\subsubsection{Hopper/feeding chute:}

The hopper assembly is a rectangular box (tray-like) with dimensions of $520 \times 475 \times$ $140 \mathrm{~mm}$ (Figure 2). It is made from mild steel plate, reinforced with angle iron, and it is attached permanently to the main frame. It is designed mainly to hold some peeled cassava tubers while the operator feeds tubers singly through the feeding chute. The feeding chute is incorporated into the hopper assembly. It is an inclined plane at an angle of $40^{\circ}$ to the horizontal, which is the angle of internal friction between the tuber and the material of construction. It is designed to pilot the peeled cassava tuber into the chipping unit. The feeding chute is $150 \mathrm{~mm}$ long and $130 \mathrm{~mm}$ wide, which is large enough to take the biggest tuber.

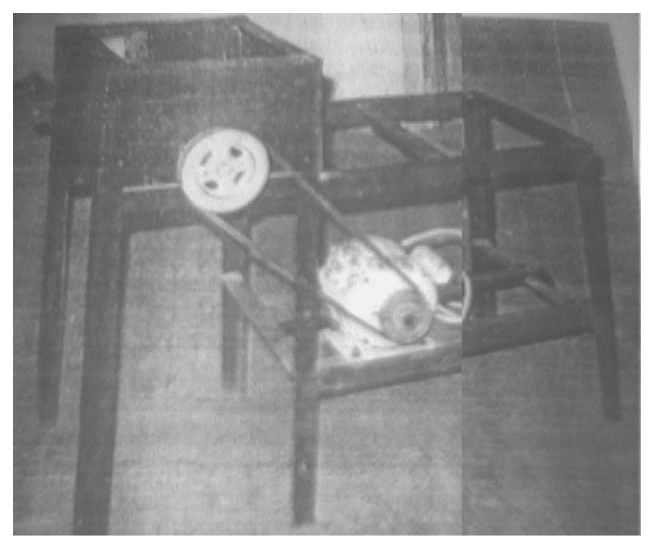

Figure 1: Cassava chipping machine

\subsubsection{Chipping unit:}

The chipping unit is a circular case housing the rotor plate and the chipping blades. It extends downwards towards a discharge chute inclined at an angle of $40^{\circ}$. This allows the chips to slide and drop under gravity into the collection box provided. The whole unit is fastened into the main frame support by bolts and nuts for easy assembly and dismantling, and for easy access to the chipping plate for cleaning. The collector unit is $420 \mathrm{~mm}$ in diameter and has a width of $100 \mathrm{~mm}$. The chipping plate is directly mounted on a shaft connected to a V-belt drive. The chipping plate 
is made up of the rotor plate and chipping blades. The rotor plate is of $6 \mathrm{~mm}$ thick mild steel plate, while the chipping blades are of galvanized iron steel metal.

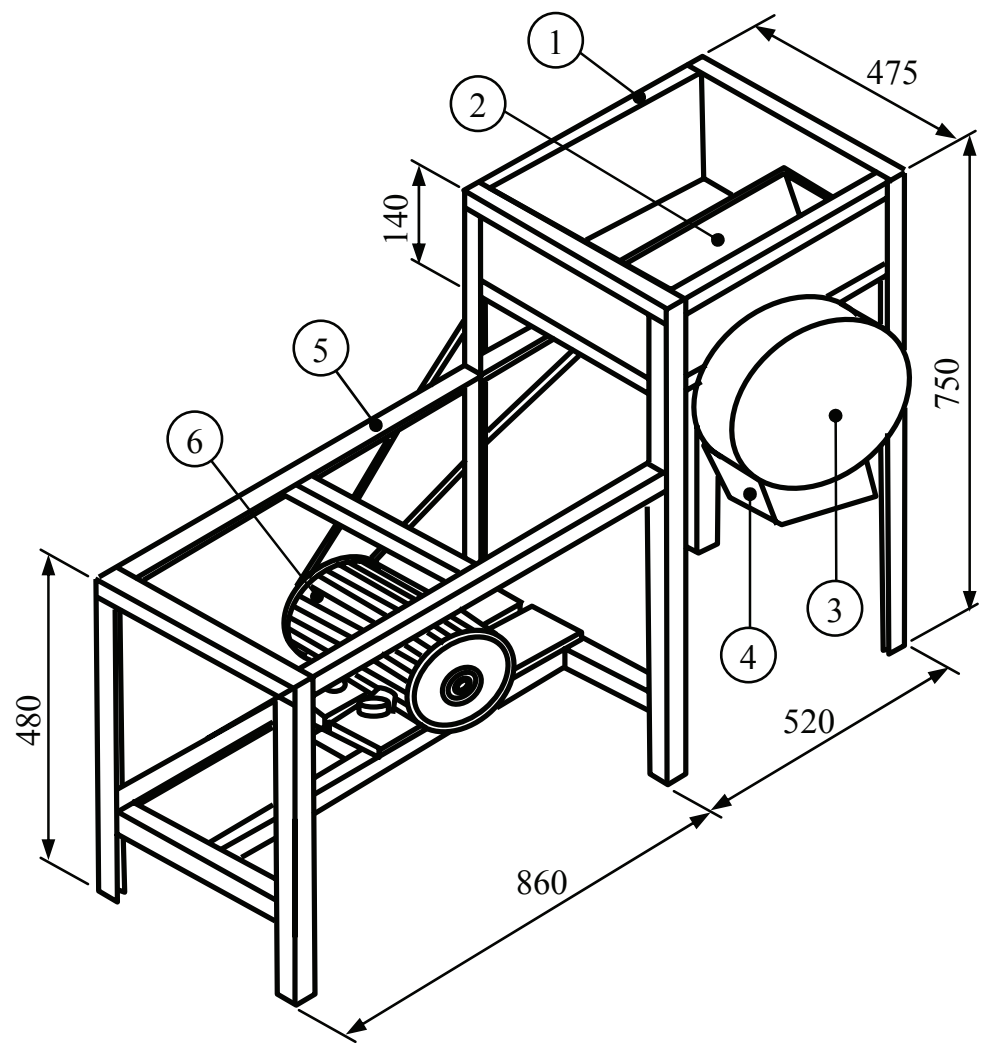

All dimensions are in millimeters.
1. Hopper
2. Feeding chute
3. Chipping unit
4. Discharge chute
5. Machine frame
6. Electric motor

Figure 2: Isometric drawing of the cassava chipping machine

\subsubsection{Power unit:}

The power unit consists of an electric motor, belt, and pulleys. The electric motor is the prime mover of the machine. It is a $1.5 \mathrm{~kW}$ Kubota electric motor with a speed of $750 \mathrm{rpm}$. The pulley of the electric motor is $168 \mathrm{~mm}$ in diameter. The machine is designed to use an open belt system of type A for power transmission from the electric motor to the chipping unit. The belt specification is A55 [10]. The electric 
motor and shaft pulleys serve as the means through which the belt transmits power from the electric motor to the shaft.

\subsubsection{Machine frame:}

The machine frame carries the components of the machine. It is made from $70 \mathrm{~mm} x$ $70 \mathrm{~mm} \times 5 \mathrm{~mm}$ angle bars welded together. The six legs of the frame form the machine stand, and are bolted to the floor to prevent vibration during operation. The machine frame is $1380 \mathrm{~mm}$ long, $475 \mathrm{~mm}$ wide, and $750 \mathrm{~mm}$ high.

\subsubsection{Operation of the machine:}

The machine is simple to operate and so requires only one operator. Before it is operated, all the parts must be properly set and fixed or bolted together. The motorized prime mover is employed because it is the most economical for large scale production of chips [11]. As the shaft rotates, it turns the rotor plate anticlockwise and the peeled root is fed against the chipping plate. The operator feeds in tubers manually through the feeding chute. The rotation of the rotor plate performs an impact action on the tubers, and the blade mounted on the rotor plate cuts the tubers by impact-shear force to the designed sizes. The chips then press through the opening in the rotor plate and are discharged via the chute.

\section{RESULTS AN DISCUSSION}

The performance test and evaluation were carried out when the construction of the machine had been completed. It was tested with an electric motor at speeds of 300 , $350,400,450$, and $500 \mathrm{rpm}$ in order to evaluate the chipping capacity and efficiency, and the adequacy of the chip geometry. At each speed, peeled cassava tubers with a total weight of $50 \mathrm{~kg}$ were fed into the machine through the hopper. The time taken for the chipping and the weight of the output chips were noted. The results of the tests carried out are shown in Tables 1 - 3 .

From the test results, it was observed that an increase in electric motor speed results in a decrease in chipping time and an increase in chipping capacity. However, the rate of decrease and increase in chipping time and chipping capacity respectively decreases as the motor speed increases (Figure 3 ).

The curve of variation of chipping efficiency with the motor speeds is shown in Figure 4. It was deduced from this figure that the higher the motor speed, the lower the chipping efficiency. Chip spillage and losses occur at higher motor speeds, which reduce efficiency. A comparison of Figures 3 and 4 revealed that the choice of motor speed for the machine would be a compromise between chipping capacity and chipping efficiency. Overall evaluation showed that the performances at motor speeds of 350 and 400 rpm were satisfactory.

Figure 5 shows curves of the variation of chips geometry with the motor speeds. As shown in the figure, there are significant differences in the length of the chips: a speed of $500 \mathrm{rpm}$ produces the longest chips, with an average length of $42.7 \mathrm{~mm}$. There are small variations in the width and thickness with respect to motor speeds except at a speed of $450 \mathrm{rpm}$, which showed a significant difference, producing 
wider chips with an average width of $19.5 \mathrm{~mm}$. Chips with smaller dimensions are preferred, because they dry quicker and better than larger chips. Also, owing to the shorter drying time, small chips stay cleaner and are less prone to mould and insect attack. The machine produced chips with a smaller geometry at moderate speeds between 350 and $400 \mathrm{rpm}$. The best chips geometry was obtained at a motor speed of $400 \mathrm{rpm}$ with a chipping efficiency of $86.5 \%$ and a chipping capacity of $240 \mathrm{kgh}^{-1}$.

\begin{tabular}{|c|c|c|c|}
\hline $\begin{array}{l}\text { Motor speed } \\
\quad(\mathrm{rpm})\end{array}$ & $\begin{array}{l}\text { Weight of peeled } \\
\text { cassava (kg) }\end{array}$ & $\begin{array}{l}\text { Chipping } \\
\text { time(s) }\end{array}$ & $\begin{array}{l}\text { Chipping capacity } \\
\left(\mathrm{kgh}^{-1}\right)\end{array}$ \\
\hline 300 & 50 & 865 & 208 \\
\hline 350 & 50 & 769 & 234 \\
\hline 400 & 50 & 750 & 240 \\
\hline 450 & 50 & 741 & 243 \\
\hline 500 & 50 & 735 & 245 \\
\hline
\end{tabular}

Table 1: Chipping time and chipping capacity at different motor speeds

\begin{tabular}{|c|c|c|c|}
\hline $\begin{array}{c}\text { Motor Speed } \\
\text { (rpm) }\end{array}$ & $\begin{array}{c}\text { Weight of the output } \\
\text { chips (kg) }\end{array}$ & $\begin{array}{c}\text { Loss in weight of } \\
\text { cassava (kg) }\end{array}$ & $\begin{array}{c}\text { Chipping } \\
\text { efficiency (\%) }\end{array}$ \\
\hline 300 & 46.28 & 3.72 & 92.6 \\
\hline 350 & 45.42 & 4.58 & 90.8 \\
\hline 400 & 43.25 & 6.75 & 86.5 \\
\hline 450 & 41.87 & 8.13 & 83.7 \\
\hline 500 & 41.03 & 8.97 & 82.1 \\
\hline
\end{tabular}

Table 2: Weight of chips produced from $50 \mathrm{~kg}$ input cassava at different motor speeds

\begin{tabular}{|cccc|}
$\begin{array}{c}\text { Motor speed } \\
(\mathrm{rpm})\end{array}$ & $\begin{array}{c}\text { Average length of } \\
\text { chips }(\mathrm{mm})\end{array}$ & $\begin{array}{c}\text { Average width of } \\
\text { chips }(\mathrm{mm})\end{array}$ & $\begin{array}{c}\text { Average thickness } \\
\text { of chips (mm) }\end{array}$ \\
\hline 300 & 30.5 & 16.7 & 7.9 \\
\hline 350 & 25.9 & 17.1 & 7.3 \\
\hline 400 & 25.4 & 16.8 & 6.8 \\
\hline 450 & 32.3 & 19.5 & 8.1 \\
\hline 500 & 42.7 & 16.6 & 8.4 \\
\hline
\end{tabular}

Table 3: Three axial dimensions of the chips produced at different motor speeds 


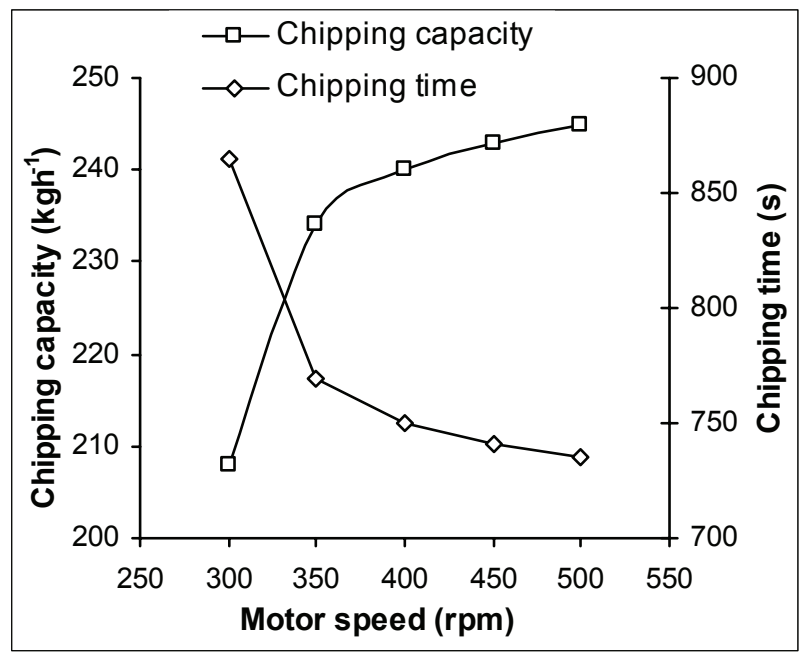

Figure 3: The curves of variation of chipping capacity and time with motor speeds

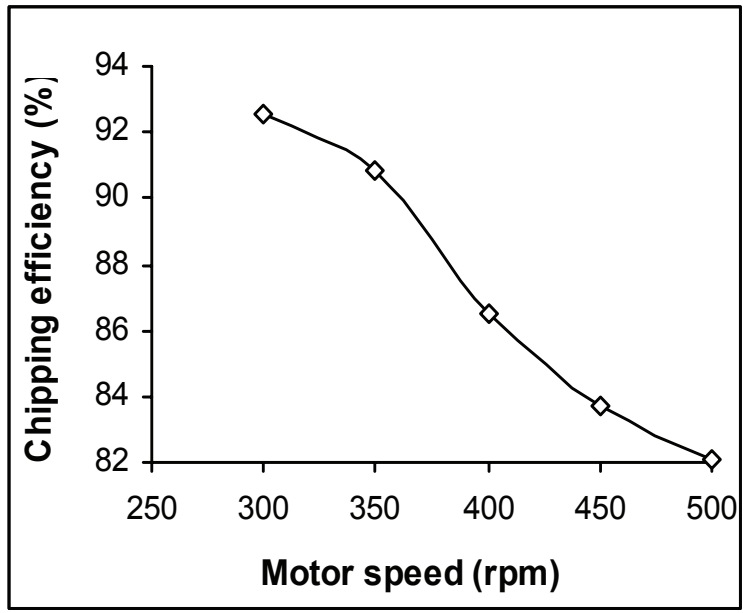

Figure 4: The curve of variation of chipping efficiency with motor speeds 


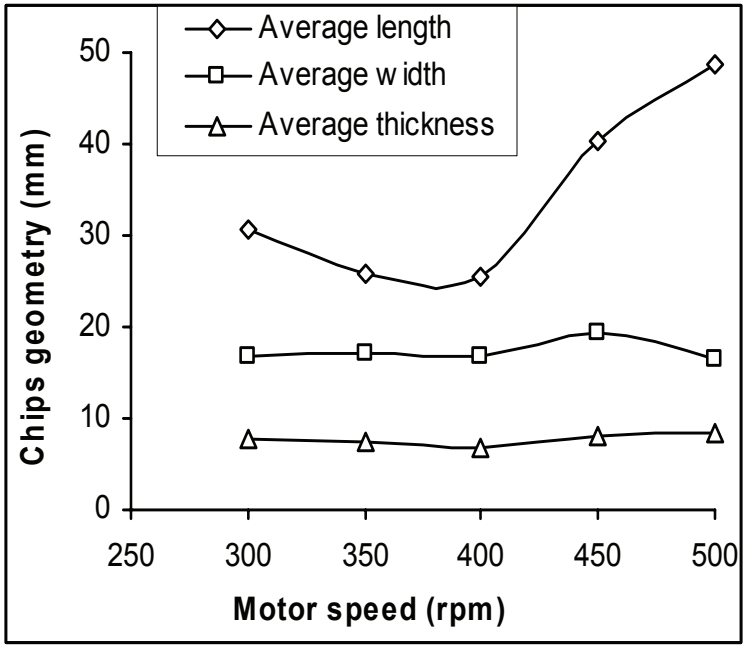

Figure 5: The curves of variation of chips geometry with motor speeds

\section{CONCLUSION}

A cassava chipping machine was designed, constructed with locally sourced materials, and its performance evaluated. The test results show that an increase in motor speeds results in a decrease in chipping time and an increase in chipping capacity. The results also reveal that the higher the motor speeds, the lower the chipping efficiency. Therefore, the choice of motor speed for the machine will be a compromise between chipping capacity and chipping efficiency. Motor speed also has significant effect on the length of chips, especially at high speeds. The best chips geometry was obtained at moderate motor speeds. The machine has a maximum capacity of $245 \mathrm{kgh}^{-1}$ at a speed of $500 \mathrm{rpm}$, and a maximum chipping efficiency of $92.6 \%$ at a speed of $300 \mathrm{rpm}$.

\section{REFERENCES}

[1] GTZ. 1998. Post harvest systems. GTZ Root and Tuber Development Guides. Newsletter, No. 1, December, 1998. http://www.gtz.de/postharvest.

[2] Odigboh, E.U. 1996. Small medium scale farmer oriented mechanization: A choice strategy for energizing Nigerian agriculture. Proceedings of 1995 NSAE Annual Conference, 96-115. 
[3] Jekayinfa, S.O., Olafimihan, E.O. and Odewole, G.A. 2003. Evaluation of pedal-operated cassava grater. LAUTECH Journal of Engineering and Technology, Vol. 1 No. 1, 82-86.

[4] Igbeka, J.C., Jony, M. and Griffon, D. 1992. Selective Mechanization for cassava process. Journal of Agriculture Mechanization in Asia, Africa and Latin America, Vol. 23 No. 1, 45-50.

[5] Ariavie, G.O. and Ohwovoriole, E.N. 2002. Improved Ohwovoriole's rotary cassava tuber peeling machine. Nigerian Journal of Engineering Research and Development, Vol. 1 No. 2, 61-63.

[6] Adejuyigbe, S.B. and Bolaji, B.O. 2005. Design, fabrication and performance evaluation of bean dehuller. Journal of Science and Technology, KNUST, Kumasi, Ghana, Vol. 25 No. 1, 125-132.

[7] Ohwovoriole, E.N., Oboli, S. and Mgbeke A.C.C. 1988. Studies and preliminary design for a cassava peeling machine. Transactions of the ASAE, Vol. 31, No. 2, 380-385.

[8] Ukatu, A.C. 2002. Development of an industrial yam peeler. Nigerian Journal of Engineering Research and Development, Vol. 1 No. 2, 45-56.

[9] Hall, A.S., Holowenko, A.R. and Laughlin, H.G. 1988. Theory and problems of machine design, Schaum's Outline Series. S.I. (metric) edition, McGraw-Hill Book Company, New York.

[10] Shingley, J.F. 1990. Mechanical engineering design. $6^{\text {th }}$ edition, McGrawHill Book Company, New York.

[11] Villanneva, M.R. 1985. Technology for cassava production in South-East Asia. Cassava Newsletter, Vol. 7 No. 1, 7. 